Dissertation

\title{
Multinational enterprises and limits to international growth
}

\author{
Guus Hendriks ${ }^{1}$ a \\ 1 University of Amsterdam, The Netherlands \\ Keywords: country portfolio, mne home country activities, foreign entry and exit decisions, behavioral perspective, added cultural distance \\ 10.46697/001c.18244
}

\section{AIB Insights}

\begin{abstract}
My doctoral research addresses the limits to international growth that multinational enterprises (MNEs) face, with a particular focus on the role of the home country within a portfolio of international activities. The importance of that market, in combination with several types of home-country uncertainties, may limit the attention devoted by MNE managers to internationalization, evidenced by lower added cultural distance. Similarly, the net growth of an MNE's country portfolio may be limited by cultural and economic diversity within that portfolio, but it also hinges on how well the MNE is performing relative to its aspirations. In an emerging market context, an 'upgrading paradox' seems to apply, as firms face important recombination barriers to growth.
\end{abstract}

\section{BIG QUESTION}

How do firms' domestic activities and domestic environments shape their international growth strategies? How do international expansion moves affect firms' domestic activities?

How do characteristics of a portfolio, and evaluations of that portfolio, influence the growth direction taken by a firm?

\section{INTRODUCTION}

International growth by multinational enterprises cannot be fully understood without an appreciation of important factors that limit international expansion; factors such as firms' domestic footprint and the composition of their country portfolios. Over the 50-odd years since the inception of the field of international business (IB), scholars have addressed many different aspects of international growth strategies, such as speed and selection in the internationalization process, or foreign entry strategies. IB scholars are in a unique position to shed light on the broader phenomenon of firms' internationalization, as they draw on IB-specific theories of the multinational enterprise. However, possibly because of the specific focus of such theories, certain biases developed over time in the IB literature, which my dissertation aimed to address in an attempt to restore balance in that literature.

First, my dissertation research addressed a bias in the IB literature towards the foreign activities of MNEs. The focus on such questions as why multinationals exist, how they enter foreign markets, and how they expand internationally, may have prompted the field to overlook that many MNEs still perform the bulk of their activities in their respective home countries. As such, home-country contexts may leave important traces on the internationalization patterns of firms. Thus, it is important to study a firm's domes- tic footprint and consider how it interacts with domestic environmental uncertainties to subsequently shape internationalization strategies. In a similar vein, little is known about the reverse side of that relationship, namely how internationalization moves affect a firm's domestic activities, even though many such moves are made with the domestic market in mind.

Second, the IB literature tended to be characterized by a bias towards individual events in relation to (de)internationalization, until recent studies emphasized the relevance of interdependencies in firm portfolios (Hendriks, 2020a; Hutzschenreuter \& Voll, 2008). My dissertation research contributes to that literature stream by looking at the relationship between a firm's domestic footprint and additions to portfolios, as well as the understudied link between portfolio characteristics and decision makers' chosen adjustments of such a portfolio. Both the focus on firms' domestic activities and their country portfolios allows this dissertation to paint a more complete picture of firms' international growth strategies and the possible limits they face in their expansion trajectory.

\section{DISSERTATION OVERVIEW}

My dissertation examined firms' domestic footprint and the ways in which it shapes their internationalization strategies. Many of the largest MNEs worldwide still perform a substantial share of their activities in their domestic markets and are thus said to have a sizeable domestic footprint. For example, the retailers I examined generate about 60 to $70 \%$ of their sales in their respective home countries. Yet, there are marked differences between them as it comes to the markets that are part of their country portfolios. UKbased retailer Tesco, for example, has activities in several Eastern European countries, but is also actively present throughout South-East Asia. Lidl, on the other hand, chose to first internationalize to countries that are relatively sim- 
ilar in cultural terms to its home country Germany. That is, the cultural distance it adds to its country portfolio at individual steps of internationalization seems to be lower than the distance added by Tesco. My dissertation research found that an MNE's decision to add cultural distance to its portfolio depends to a considerable degree on attention devoted to its home country, in relation to the importance of that market and several types of domestic uncertainties. I drew on the attention-based view and resource dependence theory to argue that such footprints likely lead senior executives to devote more attention to their home market, which goes at the expense of the attention devoted to internationalization as represented by smaller amounts of cultural distance added to a firm's portfolio. However, this relationship is contingent upon two types of domestic uncertainties about local resource contributions. More endogenous types, such as policy uncertainty, lead executives to devote even more headquarters attention domestically, whereas the exogenous domestic demand uncertainty that cannot be influenced leads firms to allocate relatively more headquarters attention to foreign expansions to hedge against that uncertainty. It can therefore be expected that firms react differently to the policy uncertainty caused by political events such as Brexit or the US election than to the market uncertainty associated with an economic recession. For example, soon after President Trump took office, several CEOs of retail firms jointly met him at the Oval Office to talk about the important role that the retail industry plays in the US economy and to convince him to take a thoughtful approach to tax reform (Hendriks, Slangen, \& Heugens, 2018). Rather than focusing on international expansion, these firms seemed to devote more attention on their home markets to resolve policy uncertainty in a, for them, favourable way.

Another part of my dissertation equally applied a portfolio perspective, but jointly considered country entry and exit to better understand MNEs' net portfolio growth strategies. It found that the net growth of an MNE's country portfolio in the face of cultural and economic diversity within that portfolio hinges on cues as to how well the MNE is performing relative to its own past performance and the current performance of its peers. Together these performance levels are thought to represent the aspirations that MNEs have, as they want to outperform competitors and do better than they did in the past. This research thereby indicates that behavioral factors have an important bearing on international portfolio growth decisions. In an analysis of all foreign entry and exit decisions made by 186 retailers, such firms are found to restrict growth in response to diversity in their country portfolios. Their performance relative to historical and social aspirations is important, however. It also suggests that decision makers are more willing to undertake radical strategic actions when their firm's performance is below aspirations, as they further restrict growth in response to portfolio diversity. When their firm's performance is above aspirations, decision makers are not as concerned about problems associated with portfolio diversity, and are less inclined to restrict growth as a function of that diversity. Building on performance feedback theory, this research thus suggests that changes to a firm's country portfolio are shaped by the extant level of diversity in that portfolio and feedback on how well it is managed.

My dissertation research also aimed to better map the conditions that influence growth decisions, but looked at domestic productivity growth after cross-border acquisitions by emerging market multinationals. It aimed to better understand an 'upgrading paradox' and drew on new internalization theory, and the concept of resource recombina- tion in particular, to build a theoretical framework that focuses on firms' ability to recombine and meld knowledge, despite possible recombination barriers to growth. My dissertation research suggested that firms characterized by low-to-medium degrees of internationalization rely more extensively on formal structures and procedures to facilitate resource recombination efforts, which is likely to stifle the entrepreneurial activity that is needed for complex resource bundling processes. Firms characterized by mediumto-high degrees of internationalization likely build expertise and increasingly realize that rules should be interpreted as guidelines, so that they rely on better-developed resource recombination capabilities that can be used to successfully upgrade the domestic asset base. Moreover, I argued that recombination processes are co-shaped by characteristics of the acquisition itself, firm-specific aspects, as well as homeenvironment characteristics, and considers the moderating roles of relative acquisition size, whether a firm is stateowned, and the magnitude of domestic institutional voids. In a sample of 382 cross-border acquisitions by manufacturing firms from 13 emerging economies, strong and consistent support is found for the suggested hypotheses.

\section{JOINT CONTRIBUTIONS}

Four themes are central to my dissertation research. First, my dissertation shed more light on the various limits that firms face in their international growth trajectories, whether it relates to domestic activities that exhaust scarce attention (Study 1), cognitive constraints in relation to the management of portfolio diversity (Study 2), or internal recombination barriers to growth (Study 3). IB research is uniquely positioned to study firms' internationalization or various sub aspects of such processes, which may inadvertently direct attention away from the factors that limit or even prevent firms from internationalizing. Having addressed three limits to international growth, and shown in what way they exert important effects, my dissertation aims to spark further research in this area.

Second, my dissertation research highlighted the important role that a firm's home country plays for its internationalization decisions; a role that IB studies only recently started to explore in greater detail. MNEs' domestic activities are often sizeable and their home environments may leave important traces on their pattern of internationalization. Even though this stream in the IB literature has considered various home-country characteristics, a firm's domestic footprint has typically been omitted as an explanatory factor when studies aimed to explain firms' behavior outside their home market. Future IB research should study in more detail what role a firm's domestic footprint plays in internationalization processes, in addition to characteristics of their home environments. Moreover, other research opportunities relate to studying how internationalization may shape changes of such footprints; an area in some measure addressed in my dissertation.

Third, my dissertation promoted a portfolio perspective similar to that taken by recent IB studies (e.g., Hutzschenreuter \& Matt, 2017). Activities in a portfolio, including entries into new businesses and exits from existing ones, are likely to be interrelated, which calls for a broader perspective on the operations of MNEs, which themselves can be conceptualized as portfolios of operating locations. Since one of my studies for example showed that managerial responses on performance feedback take the form of a wider reflection on the entire portfolio of corporate activities, my dissertation thus contributes to those recent studies. More 


\begin{tabular}{|c|c|c|c|c|c|}
\hline & Key concepts & Theoretical lens & Empirical setting & Data and methods & Main findings \\
\hline $\begin{array}{l}\text { Study } 1 \\
\text { (Chapter 2) }\end{array}$ & $\begin{array}{l}\text { Firm's domestic } \\
\text { footprint; domestic } \\
\text { environmental } \\
\text { uncertainties; added } \\
\text { cultural distance }\end{array}$ & $\begin{array}{l}\text { Attention-based view; } \\
\text { Resource dependence } \\
\text { theory }\end{array}$ & Retail industry & $\begin{array}{l}\text { Foreign entries by } 218 \\
\text { firms from } 17 \text { home } \\
\text { countries over } 2000 \text { - } \\
2007 \text { period }(1,095 \\
\text { observations) }\end{array}$ & $\begin{array}{l}\text { A firm's domestic } \\
\text { footprint and domestic } \\
\text { uncertainties jointly } \\
\text { shape cross-cultural } \\
\text { expansion strategies, } \\
\text { different uncertainty } \\
\text { types moderate the } \\
\text { relationship in different } \\
\text { ways }\end{array}$ \\
\hline $\begin{array}{l}\text { Study } 2 \\
\text { (Chapter 3) }\end{array}$ & $\begin{array}{l}\text { Country portfolio } \\
\text { diversity; portfolio } \\
\text { growth; foreign entries } \\
\text { and exits; performance } \\
\text { relative to aspirations }\end{array}$ & $\begin{array}{l}\text { Behavioral theory } \\
\text { (performance feedback) }\end{array}$ & Retail industry & $\begin{array}{l}\text { Foreign entry and exit } \\
\text { decisions of } 186 \text { firms } \\
\text { from } 24 \text { home countries } \\
\text { over } 2001-2007 \text { period } \\
\text { (752 observations) }\end{array}$ & $\begin{array}{l}\text { The evolution of a firm's } \\
\text { country portfolio is } \\
\text { shaped by its extant } \\
\text { level of diversity and } \\
\text { feedback on how well } \\
\text { that diversity is } \\
\text { managed }\end{array}$ \\
\hline $\begin{array}{l}\text { Study } 3 \\
\text { (Chapter 4) }\end{array}$ & $\begin{array}{l}\text { Domestic productivity } \\
\text { growth; cross-border } \\
\text { acquisitions; firm's } \\
\text { degree of } \\
\text { internationalization; } \\
\text { recombination barriers } \\
\text { and capabilities }\end{array}$ & $\begin{array}{l}\text { New internalization } \\
\text { theory (resource } \\
\text { recombination) }\end{array}$ & $\begin{array}{l}\text { Manufacturing firms } \\
\text { from emerging markets }\end{array}$ & $\begin{array}{l}382 \text { cross-border } \\
\text { acquisitions by firms } \\
\text { from } 13 \text { emerging } \\
\text { economies }\end{array}$ & $\begin{array}{l}\text { The relationship } \\
\text { between a firm's degree } \\
\text { of internationalization } \\
\text { and its growth of } \\
\text { domestic productivity } \\
\text { following a cross-border } \\
\text { acquisition is U-shaped } \\
\text { and moderated by } \\
\text { factors that shape } \\
\text { recombination barriers } \\
\text { and capabilities }\end{array}$ \\
\hline
\end{tabular}

Table 1

research is needed, however, to better understand the scope of activities in an MNE's portfolio, as well as the interaction between business line and country segments in such a portfolio.

Fourth, this dissertation developed a behavioral perspective of firms' management of country portfolios, thereby contributing to recent IB studies that started to explore the relevance of performance feedback (e.g., Lin, 2014) and attention (e.g., Bouquet, Morrison, \& Birkinshaw, 2009) for the activities of MNEs. Perhaps because its origins can be traced back to economics-based theories, the field of IB has not embraced behavioral perspectives as much as adjacent fields have done. My dissertation research suggested that attention, aspirations, and the direction of aspirational performance gaps in particular, matter for firms' international growth decisions. By taking those factors in consideration, the field of IB could benefit from behavioral theory's insights and come to a more complete explanation for interfirm and intertemporal differences in managerial tendencies to pursue positive or negative international growth, as reflected by additions to a portfolio or net portfolio contraction. ${ }^{1}$

\section{IMPLICATIONS FOR BUSINESS PRACTITIONERS, POLICYMAKERS, AND EDUCATORS/STUDENTS}

My dissertation has several important practical implications, particularly for MNE managers and policymakers in the domain of foreign investment attraction and promotion. The former group may benefit from a better understanding of the limits that multinational companies face to international growth, which is of particular interest to managers of multinational enterprises from emerging economies. I found that such firms are relatively successful at improving their own domestic productivity after they perform an international acquisition. On average, firms grow domestic productivity by about $40 \%$ over the threeyear period after they make a cross-border acquisition. Yet, there is also great variation, and some firms are not able to benefit in their home market from the international acquisitions they performed. Emerging market multinationals with a relatively high degree of internationalization seem to benefit the most, while firms characterized by a medium such degree generally exhibit the lowest domestic productivity growth levels. Highly internationalized firms realize even greater post-acquisition growth in domestic productivity when they are state owned, when they internationalize from a country with limited institutional voids, or when they perform relatively large acquisitions.

Not only managers may benefit from such insights, policymakers in the domain of economic development may too take note of these implications. Although outward foreign direct investment by MNEs could bring positive development consequences for the home countries from which they internationalize, little research has been done to establish this empirically, especially in an emerging economy context (Hendriks, 2020b). My dissertation makes policymakers in emerging economies aware of an 'upgrading paradox'. That is, even though emerging market multinational enterprises may choose to internationalize through acquisitions in order to upgrade, such firms only manage to successfully upgrade when they are already sufficiently well-internationalized. Whereas prior studies typically suggested a direct link between firms' outward investment and home-country development, whether or not through the mechanism of

\footnotetext{
1 The studies referred to in this article and summarized in Table 1 are co-authored by Arjen Slangen and Pursey Heugens, whereby the first
} has been published as: Hendriks, Slangen, \& Heugens (2018). 
spillovers, it could be the case that firms need to improve their productivity first before development gains can materialize. Such gains could be direct in nature, for example, when firms are able to pay higher wages, or take the form of productivity spillovers to other firms in the home economy. Studies in the realm of development economics would typically argue that sufficient absorptive capacity needs to be in place for the materialization of spillovers, as other firms in the home economy need to be capable enough to take advantage of technologies and resource bundles that EMNEs would bring back home with them. My dissertation's findings imply that there are many factors that make upgrading processes difficult even for the investing EMNEs, let alone for other firms in the home economy. Policymakers may focus their attention on stimulating the type of outward investment that allows both the investing firm and other home-economy firms to benefit (Hendriks, 2017). In general, this dissertation suggests that they thereby consider the investor's entire portfolio and its home-economy ties, as these factors may have an important bearing on international growth trajectories of firms.

As such, educators and students may benefit from these insights, too. Most business school curricula require coursework on issues that are distinctly international in nature. In a typical IB course, however, emphasis will be placed on the foreign activities of MNEs, while their domestic activities receive much less attention. My dissertation research indicated that more attention may be justified, as domestic and foreign activities in MNE portfolios affect one another in important ways, thereby shaping how portfolio growth decisions are made.

\section{ABOUT THE AUTHOR}

Guus Hendriks (g.hendriks@uva.nl) works as an Assistant Professor of International Management at the University of Amsterdam. He holds a Ph.D. from Rotterdam School of Management, Erasmus University in the Netherlands. His research interests relate to the portfolio growth strategies of multinational enterprises and the development effects of foreign investment. His work on these topics is published in journals such as the Journal of Management Studies, UNCTAD's Transnational Corporations, and International Business Review.

Submitted: September 09, 2020 EST, Accepted: December 08, 2020 EST 


\section{REFERENCES}

Bouquet, C., Morrison, A., \& Birkinshaw, J. 2009. International attention and multinational enterprise performance. Journal of International Business Studies, 40: 108-131.

Hendriks, G. 2017. The sustainable development effects of investment by emerging-market multinationals: Shaping beneficial outcomes for home and host country. Transnational Corporations, 24(3): 73-88.

Hendriks, G. 2020a. How the spatial dispersion and size of country networks shape the geographic distance that firms add while expanding internationally. International Business Review, 29(6): 101738.

Hendriks, G. 2020b. How outward foreign direct investment affects home-country economic development: Using the eclectic paradigm to synthesize two IB literatures. Multinational Business Review, 28(4): 463-482.
Hendriks, G., Slangen, A. H. L., \& Heugens, P. P. M. A. R. 2018. How a Firm's Domestic Footprint and Domestic Environmental Uncertainties Jointly Shape Added Cultural Distances: The Roles of Resource Dependence and Headquarters Attention. Journal of Management Studies, 55(6): 883-909.

Hutzschenreuter, T., \& Matt, T. 2017. MNE internationalization patterns, the roles of knowledge stocks, and the portfolio of MNE subsidiaries. Journal of International Business Studies, 48: 1131-1150.

Hutzschenreuter, T., \& Voll, J. C. 2008. Performance effects of "added cultural distance" in the path of international expansion: The case of German multinational enterprises. Journal of International Business Studies, 39(1): 53-70.

Lin, W.-T. 2014. How do managers decide on internationalization processes? The role of organizational slack and performance feedback. Journal of World Business, 49(3): 396-408. 